University of Nebraska - Lincoln

DigitalCommons@University of Nebraska - Lincoln

Sociology Department, Faculty Publications

Sociology, Department of

4-2005

\title{
Predictors of social network composition among homeless and runaway adolescents
}

Kurt D. Johnson

University of Nebraska-Lincoln, kdj11@psu.edu

Les B. Whitbeck

University of Nebraska-Lincoln, Iwhitbeck2@unl.edu

Dan R. Hoyt

University of Nebraska-Lincoln, dhoyt2@unl.edu

Follow this and additional works at: https://digitalcommons.unl.edu/sociologyfacpub

Part of the Sociology Commons

Johnson, Kurt D.; Whitbeck, Les B.; and Hoyt, Dan R., "Predictors of social network composition among homeless and runaway adolescents" (2005). Sociology Department, Faculty Publications. 152.

https://digitalcommons.unl.edu/sociologyfacpub/152

This Article is brought to you for free and open access by the Sociology, Department of at DigitalCommons@University of Nebraska - Lincoln. It has been accepted for inclusion in Sociology Department, Faculty Publications by an authorized administrator of DigitalCommons@University of Nebraska - Lincoln. 
Published in Journal of Adolescence 28:2 (April 2005), pp. 231-248; doi: 10.1016/j.adolescence.2005.02.005 Copyright (c) 2005 The Association for Professionals in Services for Adolescents; published by Elsevier Ltd.

Used by permission.

Published online March 10, 2005.

\title{
Predictors of social network composition among homeless and runaway adolescents
}

\author{
Kurt D. Johnson, Les B. Whitbeck, and Dan R. Hoyt \\ Department of Sociology, University of Nebraska-Lincoln, \\ 739 Oldfather Hall, Lincoln, NE 68588-0324, USA \\ Corresponding author - K. D. Johnson, tel 402 472-6002, email kjohnson14@unlnotes.unl.edu
}

\begin{abstract}
Recent research on the social support networks of homeless and runaway youth suggest the social networks of runaway youth are made up largely of transient deviant peer relationships. This paper examined social network characteristics of 428 homeless and runaway adolescents from small to moderate-sized cities in four Midwestern states. We investigated size, homogeneity, and correlates of the composition of the instrumental and emotional support networks as reported by the adolescents. Results showed the networks are considerably heterogeneous, comprised of relationships from home and the street as well as family and non-related adults. Further, the composition of these networks is related to adolescent characteristics and experiences including sexual identity, abuse history, and street experience.
\end{abstract}

\section{Introduction}

\section{Social network composition among homeless and runaway adolescents}

Adolescence is a critical period in the development of social relationships. During this time relationships shift from being family centered and play-oriented to more peer-oriented and emotionally centered. Disruptions in the social and developmental trajectories of ado- 
lescents have the potential to damage the normative development of healthy social relationships. Running away and living on the streets profoundly affects adolescent social development. It weakens ties to supervising adults at home and at school, weakens or severs ties to school and neighborhood friends, and establishes unconventional ties in the street culture.

In the past decade there has been increasing interest in the impact of emotional and instrumental support provided by the social networks of runaway and homeless adolescents (McCarthy \& Hagan, 1995; Kipke, Unger, O'Connor, Palmer, \& LeFrance, 1997; Unger et al., 1998; Ennett, Bailey, \& Federman, 1999; Bao, Whitbeck, \& Hoyt, 2000). Substance use, depression, delinquency, and physical and sexual abuse have all been linked to characteristics of social networks. Runaways who report smaller, more transient networks are more likely to be exposed to or engage in high-risk behaviors (Offer, Ostrov, \& Howard, 1981; McCarthy \& Hagan, 1995; Johnson, Aschkenasy, Herbers, \& Gillenwater, 1996; Kipke, Montgomery, Simon, \& Iverson, 1997). The findings suggest that the social networks of homeless and runaway adolescents can buffer the stress and dangers of street life and alternately expose them to risky behaviors and victimization. Because adolescents typically run from abusive and highly disorganized families (Whitbeck \& Hoyt, 1999), the prevailing tenet in the literature has been that the social networks of runaway and homeless youth are homogeneous in nature, street-oriented, and composed largely of transient peer relationships with little family contact.

This study examines social network characteristics of 428 homeless and runaway adolescents from small to moderate sized cities in four Midwestern states. We investigate size, homogeneity, and correlates of the composition of the instrumental and emotional support networks as reported by the adolescents.

\section{Social networks of high-risk youth}

The development of social networks in adolescence has been described as dynamic and fluid, yet following predictable developmental trajectories (Cairns, Leung, \& Cairns, 1995). Early childhood relations are characterized by dependence on parents for support and the development of perceptions of social reality. During adolescence youth begin to rely more on friends and romantic partners for support, and through these relations develop social skills through shared experiences, emotions and knowledge (Youniss \& Smollar, 1985; Furman \& Buhrmester, 1992). Although the normative development of a system of social support is apt to occur in a variable though predictive manner, healthy adolescent development requires a balance of support from family, formal associations (teachers, counselors, etc.) and informal support systems such as friends and same-age peers (Cauce, Felner, \& Primavera, 1982).

The development of a healthy system of social support is an essential element in buffering the consequences of stress. Through healthy intergenerational relationships and peer friendships empirical evidence suggests youth gain coping skills from their social networks. Newcomb and Bagwell (1996) report greater social engagement, more expressed emotions, better cooperation and conflict management, and increased task orientation among friends compared to acquaintances. Friendship relationships support greater self-esteem and selfawareness (Ladd \& Kochenderfer, 1996), and serve as emotional and cognitive resources (Hartup, 1996). According to Frey and Rothlisberger (1996), peer relationships provide prime supportive functions in day-to-day matters, while the support of parents and family members has a primary stress-buffering effect in emergency situations. Unger and colleges 
find that effective coping skills and social support may reduce the negative effects of stressful life events in homeless youth (Unger et al., 1998).

There are a myriad of factors that interfere with the balance needed between family and friends to develop strong healthy social networks. Most often, these factors are related to disrupted family relationships. This is particularly true of runaway and homeless adolescents. These adolescents are often pushed or thrown from the home because of family problems, such as family violence and substance abuse, family conflict, and disagreements with caretakers about adolescent behavior (Yoder, Whitbeck, \& Hoyt, 2001). Whitbeck and Hoyt (1999) state the experience of leaving home at an early age "precociously severs or, at minimum, weakens primary supportive ties to caretaker adults and hastens the developmental process of turning to same-age friends" (Whitbeck \& Hoyt, 1999, p. 70). Youth who do not have the benefit of supportive ties of family come to depend upon same-age peers for support. Among runaways, the peers and associates that incorporate the new social support system are likely to be troubled themselves (Coie \& Dodge, 1983; Dodge, 1983). The result is a social network of same-age peers that while supportive, may influence the youth to adopt behaviors and subsistence strategies that violate traditional social expectations.

A modest number of studies have examined the influence of social support networks of at-risk youth. Ennew (1994) in a cross-cultural study of street youth finds that although participation in street networks may expose youth to high-risk sexual and other deviant behaviors, the networks serve a positive emotional function. These findings are similar to those of Hagan and McCarthy (1997), who report that homeless and runaway youth, by embedding themselves in a network of deviant peers, avail themselves to a tutelage relationship that increases deviant behaviors. Within the context of this deviant-peer relationship the adolescents become members of a system of social support that protects them from out-group victimization and provides them with emotional support. Johnson et al. (1996) find that street exposure defined through an earlier age and a greater amount of time on the street also increases youths chances for interacting with other street youth who themselves may be engaging in health compromising behaviors.

The social networks of homeless and runaway adolescents have been empirically tied to substance abuse. Several studies have linked participation in networks to increases in substance use (Ennew, 1994; Kipke, Montgomery, Simon, \& Iverson, 1997; Kipke, Unger, O'Connor, Palmer, \& LeFrance, 1997; Hagan \& McCarthy, 1997). Ennett et al. (1999) found that while homeless youth with a social network were more likely to use drugs and alcohol, and engage in risky-behavior, those with no reported network were almost eight times more likely to engage in such behaviors. Kipke, Montgomery, Simon, \& Iverson (1997) and Kipke, Unger, O'Connor, Palmer, \& LeFrance (1997) also report different behavioral characteristics based on social networks. Categorizing homeless youth into five distinct groups; punks/skinheads, druggies, hustlers, gang members, and loners, they found significant differences in drug use, subsistence strategies, and use of services according to group affiliation.

Social networks have been found to reduce stress and depression that affect homeless adolescents. Unger et al. (1998) report that social support decreased symptoms of depression and poor health often experienced by street youth. Bao et al. (2000) found that positive social support reduced depression, while association with deviant peers increased depression.

Few studies specifically consider the composition of homeless adolescents' social networks. Ennett et al. (1999) in a study of 327 East Coast homeless youth found that the majority of networks included someone listed as a friend (75\%), and that friends were more 
likely to be present in the network than family members, romantic partners, and sex partners. Networks were reported to be relatively small, with a mean size of 2.6 members. The network members were close in age, and the networks contained a balanced males and females. Whitbeck and Hoyt (1999) found the social networks of homeless and runaway adolescents were primarily made up of same-aged friends. The majority of adolescents in their study turned to friends for emotional support, and to relatives other than parents for instrumental support. Van der Ploeg, Gaemers, and Hoogendam (1991) found homeless youth had very small social networks and that these networks were composed largely of short-term friendship relationships. They found that over $50 \%$ of youth in their study had no contact with mothers or fathers, and that while $50 \%$ mentioned having one to three friends, when asked if they had "real" friends, $80 \%$ reported they did not.

\section{The current study}

The current study expands on the limited existing research by assessing the composition of the social networks of runaway and homeless adolescents. Specifically, we distinguish between social network members from "home" and the street. We also investigate factors that influence the composition and size of social networks. The fundamental hypothesis we test is that the social networks of homeless and runaway adolescents will be homogeneous in nature composed largely of street peer relationships.

In addition to investigating the homogeneity of social networks, we also investigate various factors that affect social network composition. Older adolescents have been found to have more diverse and balanced networks (Furman \& Buhrmester, 1992). We therefore test the hypothesis that age of homeless and runaway adolescents will be positively related to diverse social networks containing a balance of family and friends from 'home' as well as the street.

Adolescents who run away at earlier ages and have spent more time on the streets reportedly have less contact with family and have smaller social networks (Van der Ploeg \& Scholte, 1997). Accordingly we hypothesize that the number of run experiences will be associated with ties to the streets, smaller social networks, and fewer family relationships. Homeless and runaway research also indicates runaway young women spend shorter amounts of time away from home because their experiences of running away are tied to specific instances of conflict rather than long-term problems (Van der Ploeg \& Scholte, 1997). We therefore hypothesize that young women will have more social network ties to home and family than young men.

There has been little research on the salience of sexual identity in the lives of runaway and homeless adolescents. Based on findings that indicate sexual minority youth frequently find it difficult to live at home and have strained relationships with family (Remafedi, 1987; Boxer, Cook, \& Herdt, 1999), we hypothesize that youth with gay, lesbian, or bi-sexual identities will have fewer ties to home and family than heterosexual youth.

Many adolescents leave home because of physical and sexual abuse from caretakers (Janus, McCormack, Burgess, \& Harman, 1987; Whitbeck \& Simmons, 1990). Because these young people are leaving home to avoid harm, we hypothesize that those who have experienced physical or sexual abuse by a caretaker will have fewer ties to home, more street contacts, and networks composed of similarly aged peers in their social networks than those who have not experienced caretaker victimization. Research also indicates homeless and 
runaway adolescents use drugs and alcohol from three to ten times more than do normal adolescents depending on the specific substance (Fietal, Margetson, Chamas, \& Lipman, 1992) and that peer associations have been linked to substance abuse among homeless youth (Whitbeck \& Hoyt, 1999). Based on these findings, we hypothesize that drugs and alcohol use will be positively associated with peer-based networks. Finally, in accordance with findings by Hagan and McCarthy (1997) and others that street youth associate with deviant peers, we hypothesize association with delinquent peers will be positively related to peer and street-based social networks.

\section{Method}

A total of 428 young people (187 males; 241 females) were interviewed directly on the streets and in shelters by full time specially trained street interviewers in four Midwestern states (Missouri, lowa, Nebraska, Kansas). Young people were interviewed using a sampling strategy that maximized locating homeless and runaway youth in various locations in each city. Although it has been established that a truly randomly sample of homeless populations is not possible (Wright, Allen, \& Devine, 1995), this procedure at least assured that various sites were included in the sampling frame. The sampling design involved repeatedly checking locations where homeless adolescents were likely to be found in each of the study cities. The locations included shelters and outreach programs serving homeless youth, dropin centers, and various 'street' locations where young homeless persons were most likely to be located. Research has demonstrated that using sampling designs that involve multiple points of entry to homeless populations are most effective in generating a diverse sample (Burt, 1996; Koegel, Burnam, \& Morton, 1996). The outreach interviewers all had prior experience in their respective cities as youth outreach workers and brought considerable knowledge regarding optimal areas of the city for locating youth on their own. Their sampling protocol included going to these locations in the cities at varying times of the day on both weekday and weekends. Methods that include systematic sampling of site locations at different times of the day, different days of the week, and across seasons have been shown to be more effective in obtaining an for homeless populations (lachan, 1989; Dennis, Iachan, Thornberry, \& Bray, 1991). This sampling protocol was conducted repeatedly over the course of 12 months.

Since episodes of homelessness are of varying duration, the sampling over a 1-year time frame provided an increased probability of capturing youth who have short-term exposure to homelessness. Short duration sampling schemes are likely to result in samples that overrepresent the long-term, chronic, homeless population (Phelan \& Link, 1999). On the other hand sampling strategies that have inadequate inclusion of street intercepts in the sampling frame might produce underestimates of chronic populations.

Interviews were conducted in a variety of locations such as shelter interview rooms, outreach vans, apartments where youth were doubling up with friends or relatives, quiet corners of restaurants, and outside. The street interviewers underwent 2 weeks of intensive training regarding computer assisted personal interviewing (CAPI) procedures. All interviews were conducted on laptop computers and downloaded electronically to a special secure university server.

Study eligibility required young people to be between the ages of 16 and 19 years and homeless. Our definition of "homeless" mandated that the youth currently resided in a 
shelter, on the street, or was living independently (e.g. friends, transitional living) because they had run away, had been pushed out, or had drifted out of their family of origin. The adolescents were informed that this was a longitudinal study and the tracking protocols were explained. Informed consent was a two-stage process. First, the study was explained and informed consent was obtained from the adolescent. They were assured that refusal to participate in the study, refusal of any question, or stopping the interview process would have no effect on current or future services provided by the outreach agency in which the interviewer was placed. Second, all adolescents were asked if we could contact their parents. If permission was granted, parents were contacted and informed consent to talk to a minor under 18 years was verbally obtained. The parents also were asked to participate in a computer assisted telephone interview. Results from the parent interviews are not discussed in this study. If the adolescent was sheltered, we followed shelter policies of parental permission for placement and guidelines concerning of loco-parentis for granting such permissions. These policies were always based on state laws. In the few cases where the adolescent was under 18 years, not sheltered, and refused permission to contact parents, the adolescents were treated as emancipated minors in accord with National Institute of Health guidelines (Department of Health and Human Services, 2002). The consent process and questionnaires were approved by the University of Nebraska-Lincoln Institutional Review Board (\#2001-07-333 FB). A National Institute of Mental Health Certificate of Confidentiality was obtained to protect the respondent's statements regarding potentially illegal activities (e.g. drug use).

Interviews were conducted in two parts. The first interview consisted of a social history and symptom scale and the second interview consisted of diagnostic items (not used in these analyses). Based on interviewer reports, approximately $90 \%$ of the adolescents who were approached for an initial interview and who met study criteria agreed to participate in the study. Respondents were paid $\$ 25$ for each interview.

\section{Measures}

\section{Demographics}

Age of respondent was continuous, and dichotomous variables were created for gender ( 0 male, 1 female); race ( 0 white, 1 non-white); and sexual identity ( 0 heterosexual, 1 gay, lesbian, or bisexual).

Peer delinquent behaviors was measured using a 12-item scale that asked adolescents if any of their friends had engaged in deviant behaviors. Delinquent behaviors included running away, selling drugs, using drugs, suspension from school, dropping out of school, shoplifting, breaking and entering, stealing, selling sex, being arrested, and threatening or assaulting someone with a weapon (Whitbeck \& Simmons, 1990). The response categories for each item was $0=$ no and 1 = yes. The summated scale ranged from 0 to 12 . High scores indicate association with peers who engage in more delinquent behaviors. Cronbach's $\alpha$ for this scale of delinquent peers was .87 .

Adolescents were asked to report the number of times they had left home since the first time they ran. While some individuals were contacted during their first run episode, the majority had numerous experiences with running from home. Ever stayed on the street was measured by asking youth if they had ever spent one or more nights on the street in an abandoned building or another place out in the open. 
Victimization when the adolescents were on their own was measured with a series of six questions in which the adolescents were asked to report how often they had been victimized since they had left home. Specifically adolescents were asked, "Since you have been on your own, how often have you been.." beaten up, robbed, asked to do something sexual, sexually assaulted or raped, threatened with a weapon, or assaulted with a weapon. Response categories were never, once, two to five times, and more than five times. The mean scale has an alpha reliability of .72 and ranges from 0 to 3 with higher scores indicating more frequent victimization.

Caretaker abuse was assessed by a questions adapted from the Conflict Tactics Scale (Straus \& Gelles, 1990). The youth were asked to report how often they had been punished by being made to go a day without food or water, been abandoned for at least $24 \mathrm{~h}$, had something thrown at them in anger, been pushed, shoved or grabbed in anger, been slapped in the face or head with an open hand, been hit with some object, been beaten with fists, been verbally or physically threatened with a gun or knife, been wounded with a gun or knife, been asked to do something sexual, or been forced to do something sexual. Response categories were never, once, two to five times, and more than five times. The mean scale has an alpha reliability of .84 and a range of $0-3$ with higher numbers indicating a greater frequency of experiencing abuse.

Depressive symptoms were assessed with 20 items from the CES-D (Radloff, 1991). Items asked respondents to report the number of days in the past week they felt happy, felt people were unfriendly, slept restlessly, felt sad, enjoyed life, had crying spells, felt hopeful about the future, felt they were as good as other people, felt people disliked them, felt bothered by things, thought their life was a failure, felt like not eating, could not get going, felt lonely, had trouble concentrating, could not shake off the blues, felt everything was an effort, felt fearful, talked less, and felt depressed. Variables were recoded so that higher values indicated more depressive symptoms. The summated scale has an alpha reliability of .87.

Frequency of alcohol use was measured using the mean of two items that asked respondents to report how often in the past year did they drink alcohol. Respondents were asked how frequently in the last 12 months they drank beer and how frequently in the last 12 months they drank hard liquor. Response categories were never, a few times, monthly, weekly, and daily.

Hard drug use was a computed measure using a series of questions in which the respondents indicated how frequently in the past 12 months they had used; crank, other amphetamines, cocaine, opiates, hallucinogens, barbiturates, or inhalants. Response categories were never, a few times, monthly, weekly, and daily. The items were meaned and then the scale was dichotomized to indicate any use of hard drugs. Frequency of marijuana use was measured using a single item indicator asking respondents to report how frequently in the past 12 months they had used marijuana.

\section{Social network characteristics}

To assess the composition of the social networks of runaway and homeless adolescents, a series of dichotomous indicators were used. Respondents were asked to provide information about their close instrumental and emotional ties. For instrumental support, respondents were asked; "Are there people in your life you can count on to give you help and aid? People who may lend you money, give you food, or give you a place to stay without asking for anything in return?" For emotional support, respondents were asked; "Are there people 
in your life you can count on to care about you, no matter what is happening to you? People that accept you totally, including your good and bad points, people who are ready to accept you when you are upset, and who are really concerned about your feelings and welfare?" Adolescents reported the relationship, age, gender, and location (street or home indicating if the adolescent established the relationship prior to or after running away) of up to 3 members of their instrumental network and up to 3 members of their emotional network. Using a count procedure, individual dichotomous measures were created indicating if the youth reported anyone in their network specifically as being a parent, another family member, a significant other, a friend, a non-related adult, or a professional. In all cases, those who had at least one member present in their network were given a value of one and those who did not a value of zero. Additionally variables were created indicating if the network member came from home or from the street and if they were male or female. As a means of controlling for network size and overlapping of emotional and instrumental networks, a variable for total number of individuals listed in their reported network is included and has a range from 0 to 6 .

Logistic regression was used to investigate factors associated with composition of the youths' social networks. This analysis uses dichotomous dependent variables that indicate whether respondents had at least one member of their network from the street, from home, who was a parent, who was another relative, who was a non-related adult, who was a significant other, who was a friend, or who was a professional. To control for size and overlap of adolescent social networks a variable for total size of reported network was included in the regression models.

\section{Results}

\section{Sample characteristics}

The sample was almost evenly divided between males (44\%) and females (56\%). Ages ranged from 16 to 19 years with a mean of 17.4 years. In terms of race/ethnicity, $59 \%$ of the sample was European American, 22\% were non-Hispanic African American, 5\% were Hispanic, and the remaining 14\% self-identified as American Indian, Asian or Pacific Islander, or bi-racial. Approximately $15 \%$ of the sample identified as gay, lesbian, or bisexual.

Many of these young people have run from home for the first time at an early age (Mean $=13.4$ years; $S D=2.97$; median $=14)$. Approximately half of the sample $(49 \%)$ had spent at least one night directly on the streets. High rates of abuse are also characteristic of this sample with $25 \%$ being sexually abused on at least one occasion. Broken down by gender, $12 \%$ of males and $36 \%$ of females had been sexually abused. Almost everyone in the sample (95\%) had been physically abused or neglected on at least one occasion. Similar rates were reported for males and females (93\% and 97\%, respectively).

An analysis of the history of homelessness among the sample demonstrated a substantial variability for amount of time that youth had been on their own. Based on the life history interviews, only $7.8 \%$ of the youth had spent 7 days or less living in shelters, being on the street, or in unsupervised living situations prior to being recruited for the study. Approximately $9.0 \%$ had been on their own more than a week but less than a month, and another $11.6 \%$ from between 1 and 3 months. Thus, slightly over one-fourth of the sample (28.4\%) had histories of being on their own for less than three months. At the other end of the distribution, over one-third of the sample (36.2\%) had been on their own for more than a year. In 
sum, the procedures used have produced a sample of homeless youth that has greater variability in chronicity of homelessness than might be anticipated in short-term point-prevalence studies.

\section{Bivariate analyses}

Table 1, Table 2, and Table 3 display the percentage of respondents indicating at least one member of their reported social network members by gender, sexual orientation, and race.

Table 1 reports the percentages for the overall social network of the respondents (either instrumental or emotional). Females were significantly more likely to report networks members from home and overall network members as being family members other than parents. Gender of network members were significantly related to the gender of the respondent. Males were more likely to report males in their network and females were more likely to report other females.

By sexual orientation, those adolescents reporting a GLB identity were significantly more likely to report network members from the street as part of their overall network. As well, GLB youth were more likely to report a family member other than parent, friends, and professionals as part of their overall network. Non-white respondents were significantly more likely to report overall network members from the street, as family members other than parents, friends and professionals.

Table 2 reports the percentages for the instrumental network of respondents. Females were significantly more likely to report instrumental network members from home, as family members other than parents, as significant others, and as professionals. Youth with a GLB sexual orientation were more likely to report instrumental network members as coming from

Table 1. Percentage listing at least one member in network (total network either instrumental or emotional)

\begin{tabular}{|c|c|c|c|c|c|c|c|c|c|}
\hline & \multicolumn{3}{|c|}{ Gender of respondent } & \multicolumn{3}{|c|}{ Sexual orientation } & \multicolumn{3}{|l|}{ Race } \\
\hline & Total & Male & Female & Total & Heterosexual & GLB & Total & White & Non-white \\
\hline \multicolumn{10}{|l|}{ Location } \\
\hline Street & 47.2 & 48.1 & 46.5 & 47.1 & $43.6^{* * *}$ & 67.7 & 47.1 & $44.0^{+}$ & 51.4 \\
\hline Home & 78.0 & 71.7 & $83.0 \% *$ & 78.2 & 78.4 & 77.4 & 78.4 & 79.2 & 77.1 \\
\hline \multicolumn{10}{|l|}{ Relationship } \\
\hline Parent & 31.5 & 27.8 & 34.4 & 31.6 & 32.1 & 29.0 & 31.8 & 31.6 & 32.0 \\
\hline Other family & 48.4 & 43.3 & $52.3 *$ & 49.9 & $52.1 *$ & 37.1 & 50.1 & $47.2^{+}$ & 54.3 \\
\hline Significant other & 25.0 & 22.5 & 27.0 & 25.1 & 25.2 & 24.2 & 24.9 & 24.4 & 25.7 \\
\hline Friend & 71.3 & 68.4 & 73.4 & 71.2 & $69.6^{*}$ & 80.6 & 71.3 & $74.4^{+}$ & 66.9 \\
\hline Non-related adult & It 10.7 & 8.0 & 12.9 & 10.8 & 11.2 & 8.1 & 10.9 & 10.8 & 10.8 \\
\hline Professional & 10.5 & 11.8 & 9.5 & 10.5 & $9.0 *$ & 19.4 & 10.4 & $8.4^{+}$ & 13.1 \\
\hline Street family & 1.6 & 2.1 & 1.2 & 1.6 & 1.4 & 3.2 & 1.6 & 1.2 & 2.3 \\
\hline \multicolumn{10}{|c|}{ Gender of network member } \\
\hline Male & 70.8 & 77.5 & $65.6 * *$ & 70.7 & 69.6 & 77.4 & 70.8 & 72.4 & 68.6 \\
\hline Female & 80.8 & 75.9 & $84.6^{*}$ & 81.0 & 80.3 & 85.5 & 80.9 & 81.2 & 80.6 \\
\hline
\end{tabular}

$+P<.10 ; * P<.05 ; * * P<.01$ 
Table 2. Percentage listing at least one member in instrumental network

\begin{tabular}{|c|c|c|c|c|c|c|c|c|c|}
\hline & \multicolumn{3}{|c|}{ Gender of respondent } & \multicolumn{3}{|c|}{ Sexual orientation } & \multicolumn{3}{|l|}{ Race } \\
\hline & Total & Male & Female & Total & Heterosexual & GLB & Total & White & Non-white \\
\hline \multicolumn{10}{|l|}{ Location } \\
\hline Street & 38.3 & 38.5 & 38.2 & 38.2 & $35.3^{* *}$ & 54.8 & 38.1 & 36.8 & 40.0 \\
\hline Home & 66.4 & 58.8 & $72.2^{* * *}$ & 66.5 & 66.8 & 64.5 & 66.6 & 68.0 & 64.6 \\
\hline \multicolumn{10}{|l|}{ Relationship } \\
\hline Parent & 11.9 & 10.2 & 13.3 & 11.9 & 11.8 & 12.9 & 12 & 12.8 & 10.9 \\
\hline Other family & 30.6 & 24.6 & $35.3 *$ & 31.9 & 32.6 & 27.4 & 32 & $26.4 * *$ & 40 \\
\hline Significant other & 16.1 & 12.3 & $19.1 *$ & 16.2 & 16.4 & 14.5 & 16.2 & 16.0 & 16.6 \\
\hline Friend & 61.4 & 59.4 & 63.1 & 61.4 & 61.1 & 62.9 & 61.4 & $65.2 *$ & 56.0 \\
\hline Non-related adult & It $\quad 8.6$ & 6.4 & 10.4 & 8.7 & 8.8 & 8.1 & 8.7 & 8.8 & 8.6 \\
\hline Professional & 6.5 & 9.1 & $4.6 *$ & 6.6 & 6.0 & 9.7 & 6.4 & 5.2 & 8.0 \\
\hline Street family & 1.4 & 1.6 & 1.2 & 1.4 & 1.1 & 3.2 & 1.4 & .8 & 2.3 \\
\hline \multicolumn{10}{|c|}{ Gender of network member } \\
\hline Male & 57.0 & 65.2 & $50.6^{* * *}$ & 56.9 & 56.7 & 58.1 & 56.9 & 59.6 & 53.1 \\
\hline Female & 63.6 & 50.3 & $73.9 * *$ & 63.7 & 62.2 & $72.6^{+}$ & 63.8 & 64.0 & 63.4 \\
\hline
\end{tabular}

Table 3. Percentage listing at least one member in emotional network

\begin{tabular}{|c|c|c|c|c|c|c|c|c|c|}
\hline & \multicolumn{3}{|c|}{ Gender of respondent } & \multicolumn{3}{|c|}{ Sexual orientation } & \multicolumn{3}{|l|}{ Race } \\
\hline & Total & Male & Female & Total & Heterosexual & GLB & Total & White & Non-white \\
\hline \multicolumn{10}{|l|}{ Location } \\
\hline Street & 35.5 & 34.2 & 36.5 & 35.6 & $31.5^{* * *}$ & 59.7 & 35.3 & 33.2 & 38.3 \\
\hline Home & 73.6 & 67.4 & $78.4^{* *}$ & 73.8 & 74.2 & 71.0 & 73.9 & 74.0 & 73.7 \\
\hline \multicolumn{10}{|l|}{ Relationship } \\
\hline Parent & 29.9 & 26.7 & 32.4 & 30.0 & 30.4 & 27.4 & 30.1 & 29.6 & 30.9 \\
\hline Other family & 40.2 & 39.0 & 41.1 & 41.7 & $44.9 * *$ & 22.6 & 41.9 & 40.0 & 44.6 \\
\hline Significant other & 20.3 & 18.7 & 21.6 & 20.4 & 20.3 & 21.0 & 20.2 & 20.8 & 19.4 \\
\hline Friend & 49.8 & 46.0 & 52.7 & 49.9 & $46.8^{* *}$ & 67.7 & 49.6 & 52.0 & 46.3 \\
\hline Non-related adult & t 5.6 & 3.7 & 7.1 & 5.6 & $6.6^{*}$ & 0.0 & 5.6 & 5.2 & 6.3 \\
\hline Professional & 6.5 & 5.9 & 7.1 & 6.6 & $4.9 * *$ & 16.1 & 6.4 & 5.2 & 8.0 \\
\hline Street family & 1.4 & 1.6 & 1.2 & 1.4 & 1.4 & 1.6 & 1.4 & .8 & 2.3 \\
\hline \multicolumn{10}{|c|}{ Gender of network member } \\
\hline Male & 60.5 & 64.7 & 57.3 & 60.7 & $58.1^{* * *}$ & 75.8 & 60.5 & 62.0 & 58.3 \\
\hline Female & 75.5 & 71.1 & $78.8^{*}$ & 75.6 & 76.2 & 72.6 & 75.5 & 75.2 & 76.0 \\
\hline
\end{tabular}

$+P<.10 ; * P<.05 ; * * P<.01$ 
the street. Non-white respondents were more likely to report family members other than parents and friends as part of their instrumental network.

Table 3 reports the percentages for the emotional network of respondents. Females were more likely to report someone from home as a member of their emotional network. GLB youth were more likely to report emotional network members from home, as friends and as professionals, and significantly less likely to report other family members as part of their emotional network.

\section{Multivariate analyses}

Table 4 reports the odds ratios for factors associated with the composition of the adolescents' emotional social network. The total size of reported network was significantly related to all compositional variables (Models 1-8) indicating that the more people reported in the social network the greater the likelihood that there would be at least one person in each category.

Age had a positive effect on whether at least one member of the emotional network was a parent. The older the adolescent, the more likely a parent would be part of his or her social network. Youth with gay, lesbian, or bisexual identity were more likely to report having a member of their emotional social network from the street, as being a friend, and as being a professional. Gay, lesbian, and bisexual youth were less likely to report other family members as part of their emotional network.

Those youth who reported abuse prior to leaving home were significantly less likely to report parents as part of their emotional network Youth who reported ever spending a night

Table 4. Odds ratios for composition of emotional network

\begin{tabular}{|c|c|c|c|c|c|c|c|c|}
\hline & $\begin{array}{l}\text { Model } 1 \\
\text { Street }\end{array}$ & $\begin{array}{l}\text { Model } 2 \\
\text { Home }\end{array}$ & $\begin{array}{l}\text { Model } 3 \\
\text { Parents }\end{array}$ & $\begin{array}{l}\text { Model } 4 \\
\text { Other } \\
\text { family }\end{array}$ & $\begin{array}{l}\text { Model } 5 \\
\text { Non-related } \\
\text { adult }\end{array}$ & $\begin{array}{l}\text { Model } 6 \\
\text { Significant } \\
\text { other }\end{array}$ & $\begin{array}{l}\text { Model } 7 \\
\text { Friend }\end{array}$ & $\begin{array}{l}\text { Model } 8 \\
\text { Professional }\end{array}$ \\
\hline Age & 1.09 & 1.02 & $1.38 *$ & 1.08 & .95 & 1.14 & 1.00 & 1.14 \\
\hline Gender & 1.18 & 1.60 & 1.35 & 1.07 & 2.06 & 1.26 & 1.20 & .67 \\
\hline Race & 1.46 & .87 & .91 & 1.13 & 1.18 & .94 & .82 & 1.59 \\
\hline Gay or bisexual & $2.73 * *$ & .66 & .85 & $.30 * *$ & .00 & .81 & $2.03 *$ & $4.00 * *$ \\
\hline Number of times run & 1.00 & 1.00 & 1.00 & .99 & 1.01 & .98 & 1.00 & .98 \\
\hline Abuse prior to leaving home & 1.08 & .84 & $.57 * *$ & .98 & 1.12 & 1.16 & 1.21 & $2.10 *$ \\
\hline Victimized on own & 1.37 & $.59^{+}$ & .94 & .86 & 1.67 & .89 & .91 & 1.09 \\
\hline Ever on street & $2.96 * *$ & $.57^{+}$ & $.56^{*}$ & $.65^{+}$ & 1.31 & $1.72^{+}$ & 1.29 & .57 \\
\hline Peers delinquent behaviors & .99 & .97 & $1.08^{+}$ &. .98 & .93 & 1.03 & 1.02 & $.85 *$ \\
\hline Depressive symptoms & 1.01 & 1.00 & 1.00 & 1.01 & 1.00 & 1.02 & 1.01 & $1.03^{+}$ \\
\hline Alcohol use & 1.11 & 1.17 & .90 & 1.00 & 1.10 & .83 & 1.11 & 1.10 \\
\hline Marijuana use & .97 & .95 & 1.01 & 1.10 & .89 & 1.08 & .90 & .80 \\
\hline Hard drug use & .83 & 1.08 & .83 & 1.13 & 1.03 & 1.22 & 1.28 & .78 \\
\hline Total size of network & $1.35^{* *}$ & $2.42 * *$ & $1.68 * *$ & $1.57^{* *}$ & $1.57^{* *}$ & $1.25^{*}$ & $1.37^{* *}$ & $1.87 * *$ \\
\hline-2 Log likelihood & 482.36 & 338.18 & 438.88 & 506.07 & 161.71 & 404.54 & 542.43 & 162.21 \\
\hline Nagelkerke $R^{2}$ & .19 & .43 & .23 & .20 & .15 & .07 & .12 & .23 \\
\hline
\end{tabular}

$+P<.10 ; * P<.05 ; * * P<.01$

$N=428$. 
on the street were significantly more likely to have street-based emotional networks and significantly more likely to report a professional as part of their emotional network. Youth that reported ever spending a night on the street were significantly less likely to report emotional network members from home, such as parents and other family members.

Runaways who had a greater association with peers who engaged in more delinquent behaviors were marginally more likely to have a parent as a member of their emotional network, and significantly less likely to report a professional as part of their emotional network.

Table 5 reports the odds ratios for factors correlated with the composition of the adolescents' instrumental social network. As with the emotional network, the total size of network was a significant predictor of nearly all of the compositional attributes (Models 1-8). Most of the factors found to be significant in predicting instrumental network members were similar to those for emotional networks. Age of respondent was marginally related to the inclusion of parents and professionals in the instrumental social network. Women were more likely than men to report someone from home as part of their instrumental network, and significantly less likely to list a professional in their instrumental network. Non-white youth were more likely to report other family members in their instrumental network, and less likely to report parents, and friends as instrumental network members.

Gay, lesbian or bisexual youth were more likely to have instrumental network members from the street than were their heterosexual counterparts. Adolescents who had experienced caretaker abuse prior to leaving home were significantly more likely to have had at least one friend in their instrumental network. Youth who had been victimized on their own were sig-

Table 5. Odds ratios for composition of instrumental network

\begin{tabular}{|c|c|c|c|c|c|c|c|c|}
\hline & $\begin{array}{l}\text { Model } 1 \\
\text { Street }\end{array}$ & $\begin{array}{l}\text { Model } 2 \\
\text { Home }\end{array}$ & $\begin{array}{l}\text { Model } 3 \\
\text { Parents }\end{array}$ & $\begin{array}{l}\text { Model } 4 \\
\text { Other } \\
\text { family }\end{array}$ & $\begin{array}{l}\text { Model } 5 \\
\text { Non-related } \\
\text { adult }\end{array}$ & $\begin{array}{l}\text { Model } 6 \\
\text { Significant } \\
\text { other }\end{array}$ & $\begin{array}{l}\text { Model } 7 \\
\text { Friend }\end{array}$ & $\begin{array}{l}\text { Model } 8 \\
\text { Professional }\end{array}$ \\
\hline Age & .88 & .90 & $1.33^{+}$ & 1.00 & .93 & .91 & .82 & $1.46^{+}$ \\
\hline Gender & .95 & $1.75^{+}$ & 1.18 & 1.36 & 1.53 & 1.58 & 1.13 & $.35 *$ \\
\hline Race & 1.34 & .68 & $.54^{+}$ & $1.73^{*}$ & .92 & 1.05 & $.58 *$ & 1.61 \\
\hline Gay or bisexual & $1.73^{+}$ & .67 & 1.36 & .80 & .82 & .73 & .67 & 1.31 \\
\hline Number of times run & 1.01 & 1.00 & .99 & 1.00 & 1.01 & .99 & 1.01 & 1.00 \\
\hline Abuse prior to leaving home & 1.25 & .80 & .68 & .76 & .65 & 1.07 & $1.73^{*}$ & 1.29 \\
\hline Victimized on own & $1.94 * \%$ & $.58 *$ & 1.30 & 1.13 & 1.77 & .94 & .72 & 1.82 \\
\hline Ever on street & $1.61^{+}$ & $.40 * *$ & $.33 * *$ & $.54 *$ & 1.25 & 1.00 & .76 & .68 \\
\hline Peers delinquent behaviors & 1.01 & $.92 *$ & 1.07 & 1.02 & $.87^{*}$ & .98 & .95 & .90 \\
\hline Depressive symptoms & 1.00 & 1.02 & .99 & 1.00 & 1.01 & 1.02 & 1.00 & 1.00 \\
\hline Alcohol use & $1.47 * *$ & 1.19 & .78 & $.73^{*}$ & .81 & 1.14 & $1.76 * *$ & 1.17 \\
\hline Marijuana use & .91 & .91 & 1.01 & 1.06 & 1.11 & 1.09 & 1.02 & .75 \\
\hline Hard drug use & 1.07 & $1.72^{+}$ & .49 & 1.01 & 1.02 & 1.03 & 1.42 & .89 \\
\hline Total size of network & $1.62 * *$ & $2.64 * *$ & $1.29 *$ & $1.36 * *$ & $1.62 * *$ & $1.35 * *$ & $2.48 * *$ & $1.40 *$ \\
\hline-2 Log likelihood & 472.80 & 351.60 & 269.71 & 471.60 & 222.00 & 353.49 & 406.73 & 178.53 \\
\hline Nagelkerke $R^{2}$ & .25 & .49 & .15 & .17 & .15 & .07 & .41 & .13 \\
\hline
\end{tabular}

$+P<.10 ; * P<.05 ; * * P<.01$

$N=428$ 
nificantly more likely to have instrumental network members from the street. Those who had ever spent time directly on the streets were more likely to have instrumental connections to the street, and less likely to have members from home, parents, or other family members in their instrumental network. Runaways who reported associating with peers who engaged in more delinquent behaviors were significantly less likely to have non-related adults in their instrumental network.

Frequent use of alcohol was positively associated with having at least one member of their instrumental network from the street, having at least one friend in their instrumental network, and negatively associated with having other family members in their instrumental network.

Table 6 reports the odds ratios for those factors predictive of compositional attributes of the adolescents' entire social network including both instrumental and emotional ties. Older adolescents were significantly more likely to have report having a parent and a professional in their social network. Non-white respondents were more likely to have network members from the street, and less likely to have friends in their network. Gay, lesbian, and bisexual identity significantly increased the likelihood of contacts from the street, and contacts with professionals. Gay, lesbian, and bisexual adolescents were significantly less likely to include other family members in their networks. Youth who reported experiencing abuse prior to running from home were significantly less likely to have parents in their network. Those youth who reported being victimized while on their own were more likely to report network members from the street, and less likely to report members from home.

Table 6. Odds ratios for composition of social network-emotional or instrumental

\begin{tabular}{|c|c|c|c|c|c|c|c|c|}
\hline & $\begin{array}{l}\text { Model } 1 \\
\text { Street }\end{array}$ & $\begin{array}{l}\text { Model } 2 \\
\text { Home }\end{array}$ & $\begin{array}{l}\text { Model } 3 \\
\text { Parents }\end{array}$ & $\begin{array}{l}\text { Model } 4 \\
\text { Other } \\
\text { family }\end{array}$ & $\begin{array}{l}\text { Model } 5 \\
\text { Non-related } \\
\text { adult }\end{array}$ & $\begin{array}{l}\text { Model } 6 \\
\text { Significant } \\
\text { other }\end{array}$ & $\begin{array}{l}\text { Model } 7 \\
\text { Friend }\end{array}$ & $\begin{array}{l}\text { Model } 8 \\
\text { Professional }\end{array}$ \\
\hline Age & .91 & 1.10 & $1.40 * *$ & 1.07 & 1.11 & 1.09 & .91 & $1.52 *$ \\
\hline Gender & .92 & 1.60 & 1.33 & 1.31 & 1.74 & 1.31 & 1.18 & .51 \\
\hline Race & $1.66^{*}$ & .71 & .83 & 1.29 & .89 & 1.09 & $.61^{+}$ & 1.67 \\
\hline Gay or bisexual & $2.27^{*}$ & .63 & .86 & $.43^{* *}$ & .57 & .73 & 1.22 & $2.30 *$ \\
\hline Number of times run & 1.00 & 1.00 & 1.00 & .99 & 1.01 & .99 & $1.03 *$ & .98 \\
\hline Abuse prior to leaving home & 1.30 & .91 & $.64 *$ & .74 & .88 & 1.11 & $1.55^{+}$ & $1.74 *$ \\
\hline Victimized on own & $1.62 \%$ & $.46 * *$ & .83 & .94 & 1.45 & .98 & .69 & 1.29 \\
\hline Ever on street & $2.42 * *$ & $.49^{+}$ & $.55^{*}$ & $.65^{+}$ & 1.13 & 1.49 & 1.20 & .67 \\
\hline Peers delinquent behaviors & 1.00 & .93 & $1.08^{+}$ & 1.01 & $.91^{+}$ & 1.00 & .94 & $.87^{*}$ \\
\hline Depressive symptoms & 1.01 & 1.02 & 1.00 & 1.01 & 1.00 & $1.02^{+}$ & 1.00 & 1.01 \\
\hline Alcohol use & $1.31 *$ & 1.09 & .86 & .93 & .83 & .89 & $1.44^{*}$ & 1.19 \\
\hline Marijuana use & .95 & .86 & 1.00 & 1.02 & 1.16 & 1.10 & 1.03 & .83 \\
\hline Hard drug use & 1.02 & 1.57 & .80 & 1.29 & .87 & 1.19 & $2.12 *$ & .75 \\
\hline Total size of network & $1.60 * \%$ & $3.13^{* *}$ & $1.75 * *$ & $1.76^{* *}$ & $1.89 * *$ & $1.42 * *$ & $2.67 * *$ & $1.73 * * *$ \\
\hline-2 Log likelihood & 490.68 & 259.62 & 442.70 & 491.52 & 251.37 & 445.52 & 353.01 & 238.19 \\
\hline Nagelkerke $R^{2}$ & .26 & .54 & .24 & .26 & .18 & .09 & .43 & .20 \\
\hline
\end{tabular}

$+P<.10 ; * P<.05 ; * * P<.01$

$N=428$. 
Table 7. Regression coefficients for total size of reported network

\begin{tabular}{lc}
\hline Variable & Standardized beta coefficients \\
\hline Age & $-.11^{*}$ \\
Gender & .06 \\
Race & .04 \\
Gay or bisexual & $.10^{*}$ \\
Number of times run & .02 \\
Abuse prior to leaving home & $-.16^{* *}$ \\
Victimized on own & -.05 \\
Ever on street & -.05 \\
Peers delinquent behaviors & .06 \\
Depressive symptoms & $-.20^{* *}$ \\
Alcohol use & .01 \\
Marijuana use & -.04 \\
Hard drug use & .08 \\
\hline
\end{tabular}

$+P<.10 ; * P<.05 ; * * P<.01$

$N=428$.

Ever spending a night on the street was positively associated with having at least one network member from the street, and negatively associated with at least on network member from home, such as parents, or other family members.

Associating with delinquent peers was positively related to naming parents as part of their overall social network, and negatively related to having non-related adults in their network. Adolescents who reported more frequent alcohol use were significantly more likely to report at least one network member from the street, and to include friends in their social network. Having used hard drugs was positively associated with name friends in the total social network.

The final ordinary-least-squares regression model investigates factors associated with total network size (Table 7). Four factors were contributed related to the total number of people in the network: age, sexual identity, caretaker abuse, and depressive symptoms. Older adolescents, those who had experienced abuse from caretakers, and those with a greater number of depressive symptoms reported fewer network members. Adolescents with gay, lesbian and bisexual identities reported a greater number of network members.

\section{Discussion}

There was considerable variation in the composition of the social networks of these runaway and homeless adolescents, and there was indication that factors associated with their experiences affected the formation of their social networks. Although previous studies (Ennett et al., 1999; Whitbeck \& Hoyt, 1999) indicate that the social networks of runaway and homeless adolescents are composed of rather homogeneous networks of peers in similar situations, these results suggest greater heterogeneity in social network composition. Nearly $80 \%$ of the adolescents reported having relationships in their overall network formed prior to 
their time on the streets. They were more likely to report friends from home (66.4\%) rather than friends on the streets (38.3\%). Also, there was a substantial number of youth who reported family members (30.6\%) as part of their total social network. This challenges the contention that runaway and homeless youth are cut off from supportive family ties. Although these ties may certainly be weakened, it is apparent that the youth still have both instrumental and emotional relationships with parents and family members. In fact, about one-third of the adolescents named a parent as a member of their instrumental (31.5\%) or emotional network (29.9\%), and nearly one-half named another family member to their instrumental (48.4\%) and emotional (40.2\%) networks. It should be noted, that the current study did not consider the quality of those relationships. Nonetheless, a significant proportion of the adolescents view their parents and other family members as resources.

The findings indicate that sexual identity may be a salient factor in the experience of homelessness and running away (Remafedi, 1987; Boxer et al., 1999). Our results suggest that gay, lesbian, and bisexual youth are considerably less likely than heterosexual youth to perceive family as instrumentally or emotionally supportive and to be more likely to depend on street friendships. Similarly, caretaker abuse prior to leaving home reduces ties to parents and family and increase ties to the streets. Those youth who have ever spent time directly on the streets are more likely to report street relationships and less likely to have ties to home.

We were puzzled to find that substance abuse had little impact on the composition of social networks. However, there were two notable exceptions: frequency of alcohol use increased the likelihood that the youth had a friend in their network, and increased the likelihood of network ties to the street. Similarly, previous research on the social networks of homeless adolescents suggests there is a deviant peer culture driving these networks (Hagan \& McCarthy, 1997). Association with delinquent peers had little impact in predicting the composition of social networks in the current study.

\section{Limitations}

This research has several important limitations that should be noted. The sample is limited to small to moderate sized cities in four Midwestern states. We view this as both as strength and a limitation. Its strength in that it documents the presence and plight of runaways in cities where they are often unacknowledged. The limitation is that the results may not be generalizable to other geographic areas or to larger metropolitan areas. Also, all of our measures are self-reports and reflect the limitations associated with adolescent reports about their social networks. Because we used a self-report measure of network member characteristics the possibility exists that there is overlap between relationships categories. A peer-nomination procedure would have provided more detailed information. Even in depth-interviews with a portion of the sample would have resulted in a clearer understanding of the complexities of their social relationships.

\section{Policy implications}

If these findings hold up, they have significant implications for intervention with homeless adolescents. Ties to neighborhood and home may be a significant source of resiliency for a significant proportion of runaways. Ties to home may mean ties to housing. Ties to 
friends at home may mean ties to a peer group that is still in school. Prevention programs that identify and build on these positive social network ties to home and more conventional peers could at once preserve important links to the community and to school and reduce integration into street networks. Facilitating supportive contacts with friends at home and in school, may lead to housing solutions other than family and at the same time maintain the adolescent in a familiar peer and school setting. Innovative interventions that involve creating supportive networks of more conventional peers and facilitating access to them may act to maintain ties to conventional norms and even serve as motivation to get off the streets.

\section{Conclusion}

The purpose of this study was to contribute to current research on homeless and runaway adolescents social networks by providing a more complete assessment of the composition of those networks and the factors that are associated with their composition. The results challenge the contention that homeless and runaway adolescent social networks are homogeneous collections of deviant-peer relationships with few ties to home and family. On the contrary, these results suggest that the networks of runaway and homeless adolescents are considerably heterogeneous, comprised of relationships from home and the street as well as family and non-related adults. Moreover, the composition of social networks is related to adolescent characteristics and their experiences. Future research should consider how the composition of these networks change over time, the impact that social network composition may have on risk trajectories, and the potential of social networks with strong "home components" to provide the critical instrumental and emotional support needed to get the adolescent off the streets.

\section{References}

Bao, Whitbeck, \& Hoyt (2000) $\triangleright$ W. N. Bao, L. B. Whitbeck, and D. R. Hoyt, Abuse, support, and depression among homeless and runaway adolescents, Journal of Health and Social Behavior 41 (2000), pp. 408-420.

Boxer, Cook, \& Herdt (1999) A. M. Boxer, J. A. Cook, and G. Herdt, Experiences of coming out among gay and lesbian youth: Adolescents alone?, In: J. Blustein, C. Levince, and N. N. Dubler, Editors, The adolescent alone: Decision making in health care in the United States, Cambridge University Press, Cambridge, UK (1999), pp. 121-138.

Burt (1996) M. R. Burt, Practical methods for counting homeless people: A manual for state and local jurisdictions (2nd ed), Urban Institute, Washington, DC (1996).

Cairns, Leung, \& Cairns (1995) $>$ R. B. Cairns, M. C. Leung, and B. D. Cairns, Social networks over time and space in adolescence. In: L. J. Crockett and A. C. Crouter, Editors, Pathways through adolescence: Individual development in relation to social contexts, Lawrence Erlbaum Associates, Mahwah (1995), pp. 35-56.

Cauce, Felner, \& Primavera (1982) - A. M. Cauce, R. D. Felner, and J. Primavera, Social support in high-risk adolescents: Structural components and adaptive impact, American Journal of Community Psychology 10 (1982), pp. 417-428.

Coie \& Dodge (1983) $>$ J. Coie and K. Dodge, Continuities and changes in children's social status: A 5-year longitudinal study, Merrill-Palmer Quarterly 29 (1983), pp. 262-282. 
Dennis, lachan, Thornberry, \& Bray (1991) $>$ M. Dennis, R. lachan, J. Thornberry, and R. Bray, The RTI method: Sampling over time. In: C. Taeuber, Editor, Enumerating homeless persons: Methods and data needs, Bureau of the Census, US Department of Commerce, Washington, DC (1991), pp. 167-170.

Dodge (1983) K K. Dodge, Behavioral antecedents of peer social status, Child Development 54 (1983), pp. 1396-1399.

Ennett, Bailey, \& Federman (1999) $>$ S. T. Ennett, S. L. Bailey, and E. B. Federman, Social network characteristics associated with risky behaviors among homeless and runaway youth, Journal of Health and Social Behavior 40 (1999), pp. 63-78.

Ennew (1994) $>$ J. Ennew, Parentless friends: A cross-cultural examination of networks among street children and street youth. In: F. Nestmann and K. Hurrelmann, Editors, Social networks and social support in childhood and adolescence, Walter de Gruyter and Co, Berlin (1994), pp. 409-426.

Fietal, Margetson, Chamas, \& Lipman (1992) $>$ B. Fietal, N. Margetson, J. Chamas, and C. Lipman, Psychosocial background and behavioral and emotional disorders of homeless and runaway youth, Hospital and Community Psychiatry 43 (1992), pp. 155-159.

Frey \& Rothlisberger (1996) $\triangleright$ C. U. Frey and C. Rothlisberger, Social support in healthy adolescents, Journal of Youth and Adolescence 25 (1996) (1), pp. 17-31.

Furman \& Buhrmester (1992) $>$ W. Furman and D. Buhrmester, Age and sex differences in perceptions of networks of personal relationships, Child Development 63 (1992), pp. 103-115.

Hagan \& McCarthy (1997) $>$ J. Hagan and B. McCarthy, Mean streets: youth crime and homelessness, Cambridge University Press, New York (1997).

Hartup (1996) $>$ W. Hartup, The company they keep: Friendships and their developmental significance, Child Development 67 (1996), pp. 1-13.

lanchan (1989) R. lachan, Sampling in Time and Space. Proceedings of the Survey Research Methods Section, American Statistical Associations (1989); http://www.amastat.org/sections/srms/Proceedings/papers/1989_116.pdf

Janus, McCormack, Burgess, \& Harman (1987) - M. Janus, A. McCormack, A. N. Burgess, and C. Harman, Histories of sexual abuse in adolescent male runaways, Adolescence 22 (1987), pp. 405-417.

Johnson, Aschkenasy, Herbers, \& Gillenwater (1996) - T. P. Johnson, J. R. Aschkenasy, M. R. Herbers, and S. A. Gillenwater, Self-reported risk factors for AIDS among homeless youth. In: AIDS education and prevention, vol. 8 (1996), pp. 308-322.

Kipke, Montgomery, Simon, \& Iverson (1997) M. D. Kipke, S. B. Montgomery, T. R. Simon, and E. F. Iverson, "Substance Abuse" disorders among runaway and homeless youth, Substance Use and Misuse 32 (1997), pp. 969-986.

Kipke, Unger, O'Connor, Palmer, \& LeFrance (1997) $\rightarrow$ M. D. Kipke, J. B. Unger, S. O'Connor, R. F. Palmer, and S. R. LeFrance, Street youth, their peer group affiliation and differences according to residential status, subsistence patterns, and use of services, Adolescence 32 (1997) (127), pp. 655-669.

Koeegel, Burnam, \& Morton (1996) $>$ P. Koeegel, M. Burnam, and J. Morton, Enumerating homeless people: Alternative strategies and their consequences, Evaluation Review 20 (1996), pp. 378-403.

Ladd \& Kochenderfer (1996) $>$ G. W. Ladd and B. J. Kochenderfer, Linkages between friendship and adjustment during early school transitions. In: A. F. Newcomb and W. W. Hartup, Editors, The company they keep: Friendship in childhood and adolescence, Cambridge University Press, New York (1996), pp. 322-345.

McCarthy \& Hagan (1995) $>$ B. McCarthy and J. Hagan, Getting into street crime: The structure and process of criminal embeddedness, Social Science Research 24 (1995), pp. 63-95.

Newcomb \& Bagwell (1996) A. F. Newcomb and C. L. Bagwell, The developmental significance of children's friendship relations. In: A. F. Newcomb and W.W. Hartup, Editors, The company they 
keep: Friendship in childhood and adolescence, Cambridge University Press, New York (1996), pp. 289-321.

Offer, Ostrov, \& Howard (1981) D D. Offer, E. Ostrov, and K. I. Howard, The adolescent, Basic Books, New York (1981).

Phelan \& Link (1999) J. Phelan and B. Link, Who are 'the Homeless'? Reconsidering the stability and composition of the homeless population, American Journal of Public Health 89 (1999), pp. 1334-1338.

Radloff (1991) L L. Radloff, The use of the center for epidemiologic studies depression scale in adolescents and young adults, Journal of Youth and Adolescence 20 (1991), pp. 149-166.

Remafedi (1987) $>$ G. R. Remafedi, Adolescents homosexuality: Psychosocial and medical implications, Pediatrics 79 (1987), pp. 331-337.

Straus \& Gelles (1990) M. Straus and R. Gelles, Physical violence in American families. Brunswick, NJ: Transaction Books (1990).

Unger et al. (1998) J. B. Unger, M. D. Kipke, T. R. Simon, C. J. Johnson, S. B. Montgomery, and E. Iverson, Stress, coping, and social support among homeless youth, Journal of Adolescent Research 13 (1998), pp. 134-157.

Van der Ploeg \& Scholte (1997) J. D. Van der Ploeg and E. M. Scholte, Homeless youth, Sage Publications, London (1997).

Van der Ploeg, Gaemers, \& Hoogendam (1991) J. D. Van der Ploeg, J. Gaemers, and P. H. Hoogendam, Homeless youth, DSWO Press, Leiden (1991).

Whitbeck \& Hoyt (1999) D L. B. Whitbeck and D. R. Hoyt, Nowhere to grow: Homeless and runaway adolescents and their families, Aldine De Gruyter, New York (1999).

Whitbeck \& Simmons (1990) $>$ L. B. Whitbeck and R. L. Simmons, Life on the streets: The victimization of runaway and homeless adolescents, Youth and Society 22 (1990), pp. 108-125.

Wright, Allen, \& Devine (1995) J J. D. Wright, T. L. Allen, and J. A. Devine, Tracking non-traditional populations in longitudinal studies, Evaluation and Program Planning 18 (1995) (3), pp. 267-277.

Yoder, Whitbeck, \& Hoyt (2001) $>$ K. A. Yoder, L. B. Whitbeck, and D. R. Hoyt, Event history analysis of antecedents to running away from home and being on the streets, American Behavioral Scientist 45 (2001), pp. 51-65.

Youniss \& Smollar (1985) J. Youniss and J. Smollar, Adolescent relationships with mothers, fathers, and friends, The University of Chicago Press, Chicago (1985).

\section{Further Reading}

R. Iachan and M. Dennis, The design of homeless surveys, Research Triangle Institute (1993). 